\title{
New Phenolic Glycosides from the Seeds of Cucurbita moschata
}

\author{
Kazuo Korke, Wei Li, Lijuan Liu, Emiko Hata, and Tamotsu NiKaido* \\ Faculty of Pharmaceutical Science, Toho University; 2-2-1 Miyama, Funabashi, Chiba 274-8510, Japan.
}

Received October 25, 2004; accepted November 22, 2004; published online November 25, 2004

Five new phenolic glycosides, cucurbitosides $\mathrm{A}-\mathrm{E}(1-5)$, were isolated from the seeds of Cucurbita moschata. Their structures were elucidated as 2-(4-hydroxy)phenylethanol $4-O$-(5- $O$-benzoyl)- $\beta$-D-apiofuranosyl $(1 \rightarrow 2)$ - $\beta$-D-glucopyranoside (1), 2-(4-hydroxyphenyl)ethanol 4- $O$-[5- $O$-(4-hydroxy)benzoyl]- $\beta$-D-apiofuranosyl $(1 \rightarrow 2)$ - $\beta$-D-glucopyranoside $(2)$, 4-hydroxybenzyl alcohol 4-O-(5-O-benzoyl)- $\beta$-D-apiofuranosyl $(1 \rightarrow 2)-\beta$-Dglucopyranoside (3), 4-hydroxybenzyl alcohol 4- $O$-[5- $O$-(4-hydroxy)benzoyl]- $\beta$-D-apiofuranosyl( $1 \rightarrow 2)$ - $\beta$-D-glucopyranoside (4) and 4-hydroxyphenyl 5- $O$-benzoyl- $\beta$-D-apiofuranosyl $(1 \rightarrow 2)$ - $\beta$-D-glucopyranoside (5) on the basis of spectroscopic analysis and chemical evidence.

Key words Cucurbita moschata; Cucurbitaceae; pumpkin seed; glycoside; cucurbitoside

Pumpkin, the fruits of Cucurbita moschata (Cucurbitaceae), has been used as a popular vegetable in cooking since antiquity and the pumpkin seeds are utilized in several countries as snacks after salting and roasting. The pumpkin seeds are also an important Traditional Chinese Medicine in the treatment of cestodiasis, ascariasis, and schistosomiasis. ${ }^{1)}$ Pharmacological studies on the seeds have demonstrated hepatoprotective ${ }^{2)}$ and antitumor activities. ${ }^{3)}$ To our knowledge, most of the chemical studies on pumpkin seeds were carried out on lipids in the pumpkin seed oil, ${ }^{4-6)}$ and no report has been published concerning the water-soluble constituents. The nutritive value and potential medicinal importance prompted us to investigate its chemical constituents, which resulted in the isolation of five new phenolic glycosides, cucurbitosides $\mathrm{A}-\mathrm{E}(\mathbf{1}-\mathbf{5})$. This paper deals with the isolation and structural elucidation of the new constituents on the basis of spectroscopic analysis and chemical evidence.

The seeds of C. moschata purchased in Harbin, China, were extracted with methanol. The methanolic extract was partitioned between ethyl acetate and water. The water layer was passed through a Diaion HP-20 column, and washed with methanol. The methanolic eluate was evaporated and applied to an ODS column chromatography (CC). Further purification by repeated reverse-phase HPLC gave five new phenolic glycosides, which were termed as cucurbitosides A-E (1-5).

Cucurbitoside A (1) was isolated as an amorphous powder. The molecular formula was established as $\mathrm{C}_{26} \mathrm{H}_{32} \mathrm{O}_{12}$ by high-resolution (HR)-FAB-MS. On acid hydrolysis, 1 af- forded D-glucose and D-apiose as component sugars, which was identified by GLC analysis of its trimethylsilyl thiazolidine derivative. $\left.{ }^{7}\right)$ The ${ }^{1} \mathrm{H}$ - and ${ }^{13} \mathrm{C}-\mathrm{NMR}$ spectra of $\mathbf{1}$ (Table 1) also revealed the presence of glucopyranose and apiofuranose moieties. The $\beta$-anomeric configuration for the glucopyranose was determined from a large ${ }^{3} J_{\mathrm{H} 1, \mathrm{H} 2}$ coupling constant value $(7.5 \mathrm{~Hz})$. The $\beta$-anomeric configuration for the apiofuranose was suggested by the chemical shift of its anomeric carbon $(\delta 110.5){ }^{8}{ }^{8}$ Besides the signals due to sugars, the ${ }^{1} \mathrm{H}-\mathrm{NMR}$ spectrum of $\mathbf{1}$ also showed a set of proton signals due to 1,4-disubstituted aromatic ring at $\delta 6.95(2 \mathrm{H}$, $\mathrm{dd}, J=8.9,1.9 \mathrm{~Hz})$ and $6.91(2 \mathrm{H}, \mathrm{d}, J=8.9 \mathrm{~Hz})$, as well as a benzylic methylene at $\delta 2.65(2 \mathrm{H}, \mathrm{td}, J=7.1,1.9 \mathrm{~Hz})$ and a hydroxymethyl at $\delta 3.62(2 \mathrm{H}, \mathrm{t}, J=7.1 \mathrm{~Hz})$, indicating the presence of a 2-(4-hydroxyphenyl)ethanol moiety. Furthermore, the signals attributable to a monosubstituted aromatic ring were observed at $\delta 7.94(2 \mathrm{H}, \mathrm{dd}, J=8.3,1.4 \mathrm{~Hz}), 7.41$ $(2 \mathrm{H}, \mathrm{t}, J=8.3 \mathrm{~Hz})$ and $7.58(1 \mathrm{H}, \mathrm{tt}, J=8.3,1.4 \mathrm{~Hz})$, in combination with the signal for a carbonyl carbon at $\delta 167.8$ in the ${ }^{13} \mathrm{C}$-NMR spectrum, suggesting a benzoyl moiety in $\mathbf{1}$. The connection of the aforementioned structural units was determined by the ${ }^{1} \mathrm{H}$-detected heteronuclear multiple bond connectivity (HMBC) data (Fig. 1). The $\beta$-D-glucopyranose was found to be connected to 4-OH of the 2-(4hydroxy)phenylethanol moiety by observation of the HMBC correlation between $\delta_{\mathrm{H}} 4.92\left(\mathrm{Glc}-\mathrm{H}-1^{\prime}\right)$ and $\delta_{\mathrm{C}} 157.3(\mathrm{C}-4)$. The $\beta$-D-apiofuranose was linked to the $2^{\prime}$-OH of $\beta$-D-glucopyranose by the HMBC correlation between $\delta_{\mathrm{H}} 5.52$ (Api$\left.\mathrm{H}-1^{\prime \prime}\right)$ and $\delta_{\mathrm{C}} 78.4($ Glc-C-2'). The connection of the benzoyl
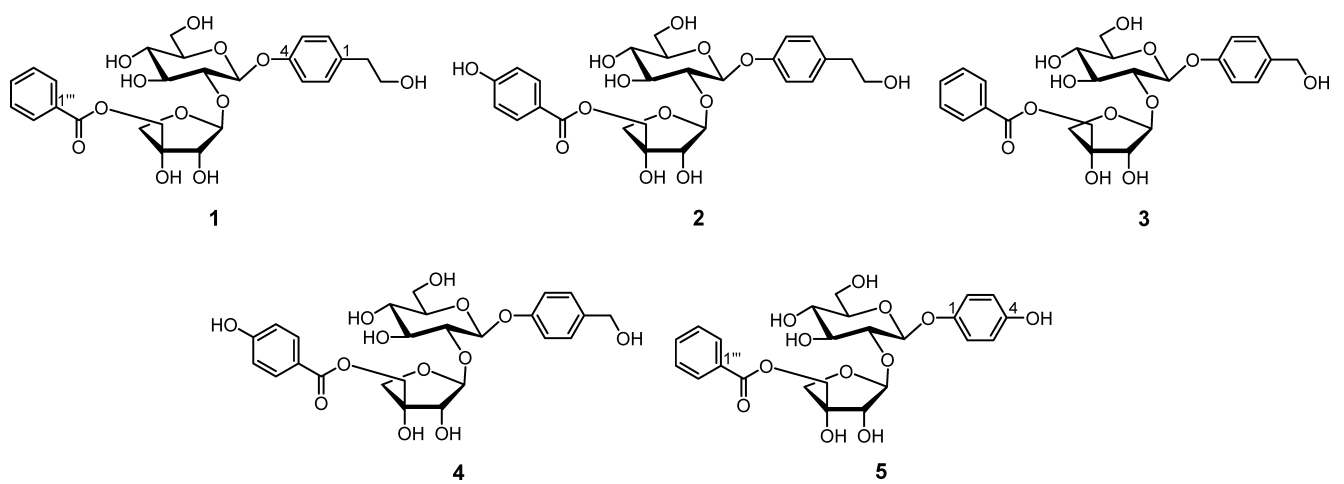

Chart 1 
Table 1. ${ }^{1} \mathrm{H}-\mathrm{NMR}$ Data of $\mathbf{1}-\mathbf{5}$ in $\mathrm{CD}_{3} \mathrm{OD}$

\begin{tabular}{|c|c|c|c|c|c|}
\hline Position & 1 & 2 & 3 & 4 & 5 \\
\hline 2 and 6 & $6.95(\mathrm{dd}, 8.9,1.9)$ & $6.96(\mathrm{dd}, 8.7,1.6)$ & $7.09(\mathrm{~d}, 8.7)$ & $7.11(\mathrm{~d}, 8.4)$ & $6.85(\mathrm{~d}, 8.9)$ \\
\hline 3 and 5 & $6.91(\mathrm{~d}, 8.9)$ & $6.90(\mathrm{~d}, 8.7)$ & $6.96(\mathrm{~d}, 8.7)$ & $6.95(\mathrm{~d}, 8.4)$ & $6.54(\mathrm{~d}, 8.9)$ \\
\hline 7 & $2.65(\mathrm{td}$ like, $7.1,1.9)$ & $2.67(\mathrm{td}$ like, $7.1,1.6)$ & $4.41(\mathrm{~s})$ & $4.44(\mathrm{~s})$ & \\
\hline 8 & $3.62(\mathrm{t}, 7.1)$ & $3.63(\mathrm{t}, 7.1)$ & & & \\
\hline Glc-1' & $4.92(\mathrm{~d}, 7.5)$ & $4.91(\mathrm{~d}, 7.6)$ & $4.95(\mathrm{~d}, 7.6)$ & $4.95(\mathrm{~d}, 7.6)$ & $4.79(\mathrm{~d}, 7.8)$ \\
\hline $2^{\prime}$ & $3.67(\mathrm{dd}, 9.1,7.5)$ & $3.66(\mathrm{dd}, 9.2,7.6)$ & $3.68(\mathrm{dd}, 9.2,7.6)$ & $3.67(\mathrm{dd}, 9.5,7.6)$ & $3.63(\mathrm{dd}, 9.1,7.8)$ \\
\hline $3^{\prime}$ & $3.60(\mathrm{t}, 9.1)$ & $3.60(\mathrm{t}, 9.2)$ & $3.61(\mathrm{t}, 9.2)$ & $3.60(t, 9.5)$ & $3.57(\mathrm{t}, 9.1)$ \\
\hline $4^{\prime}$ & $3.39(\mathrm{~m})$ & $3.38(\mathrm{~m})$ & $3.39(\mathrm{~m})$ & $3.38(\mathrm{~m})$ & $3.36(\mathrm{~m})$ \\
\hline $5^{\prime}$ & $3.40(\mathrm{~m})$ & $3.40(\mathrm{~m})$ & $3.40(\mathrm{~m})$ & $3.41(\mathrm{~m})$ & $3.36(\mathrm{~m})$ \\
\hline \multirow[t]{2}{*}{$6^{\prime}$} & $3.67(\mathrm{dd}, 12.8,5.0)$ & $3.67(\mathrm{dd}, 12.1,5.0)$ & $3.68(\mathrm{dd}, 12.1,5.3)$ & $3.68(\mathrm{dd}, 12.2,4.3)$ & $3.67(\mathrm{dd}, 12.1,5.3)$ \\
\hline & $3.86(\mathrm{dd}, 12.8,1.6)$ & $3.88(\mathrm{dd}, 12.1,1.7)$ & $3.87(\mathrm{dd}, 12.1,1.6)$ & $3.87(\mathrm{dd}, 12.2,1.9)$ & $3.86(\mathrm{dd}, 12.1,1.8)$ \\
\hline Api-1" & $5.52(\mathrm{~d}, 1.2)$ & $5.50(\mathrm{~d}, 1.1)$ & $5.52(\mathrm{~d}, 1.2)$ & $5.50(\mathrm{~d}, 1.1)$ & $5.51(\mathrm{~d}, 1.2)$ \\
\hline $2^{\prime \prime}$ & $4.01(\mathrm{~d}, 1.2)$ & $3.98(\mathrm{~d}, 1.1)$ & $4.01(\mathrm{~d}, 1.2)$ & $3.99(\mathrm{~d}, 1.1)$ & $4.02(\mathrm{~d}, 1.2)$ \\
\hline \multirow[t]{2}{*}{$4^{\prime \prime}$} & $3.92(\mathrm{~d}, 9.6)$ & $3.90(\mathrm{~d}, 9.8)$ & $3.92(\mathrm{~d}, 9.6)$ & $3.90(\mathrm{~d}, 9.6)$ & $3.91(\mathrm{~d}, 9.9)$ \\
\hline & $4.32(\mathrm{~d}, 9.6)$ & $4.32(\mathrm{~d}, 9.8)$ & $4.32(\mathrm{~d}, 9.6)$ & $4.29(\mathrm{~d}, 9.6)$ & $4.32(\mathrm{~d}, 9.9)$ \\
\hline \multirow[t]{2}{*}{$5^{\prime \prime}$} & $4.29(\mathrm{~d}, 11.4)$ & $4.22(\mathrm{~d}, 11.3)$ & $4.29(\mathrm{~d}, 11.5)$ & $4.23(\mathrm{~d}, 11.4)$ & $4.33(\mathrm{~d}, 11.4)$ \\
\hline & $4.36(\mathrm{~d}, 11.4)$ & $4.29(\mathrm{~d}, 11.3)$ & $4.35(\mathrm{~d}, 11.5)$ & $4.39(\mathrm{~d}, 11.4)$ & $4.40(\mathrm{~d}, 11.4)$ \\
\hline $2^{\prime \prime \prime}$ and $6^{\prime \prime \prime}$ & $7.94(\mathrm{dd}, 8.3,1.4)$ & $7.79(\mathrm{~d}, 8.9)$ & $7.93(\mathrm{dd}, 8.3,1.4)$ & $7.79(\mathrm{~d}, 9.0)$ & $7.96(\mathrm{dd}, 8.2,1.5)$ \\
\hline $3^{\prime \prime \prime}$ and $5^{\prime \prime \prime}$ & $7.41(\mathrm{t}, 8.3)$ & $6.75(\mathrm{~d}, 8.9)$ & $7.41(\mathrm{t}, 8.3)$ & $6.75(\mathrm{~d}, 9.0)$ & $7.42(\mathrm{t}, 8.2)$ \\
\hline $4^{\prime \prime \prime}$ & $7.58(\mathrm{tt}, 8.3,1.4)$ & & $7.58(\mathrm{tt}, 8.3,1.4)$ & & $7.58(\mathrm{tt}, 8.2,1.5)$ \\
\hline
\end{tabular}
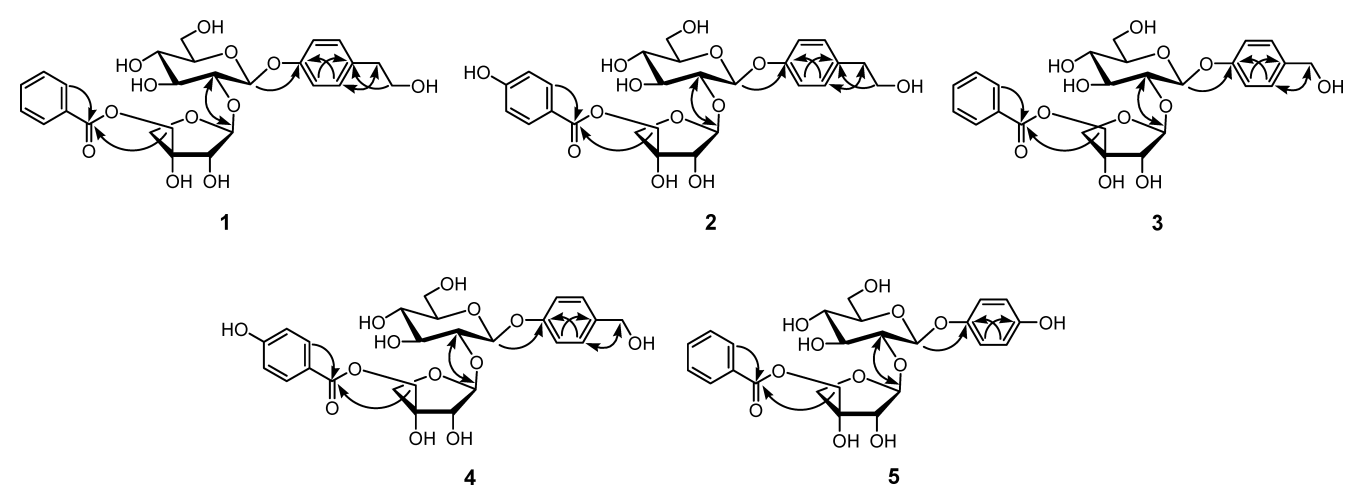

Fig. 1. Key ${ }^{1} \mathrm{H}-{ }^{13} \mathrm{C}$ Long-Range Correlations by HMBC Spectra of $\mathbf{1}-\mathbf{5}$

moiety at C- $5^{\prime \prime}$ of $\beta$-D-apiofuranose was deduced from the HMBC correlations between $\delta_{\mathrm{H}} 4.36,4.29$ (Api- $\left.\mathrm{H}^{\prime \prime}-5\right)$ and $\delta_{\mathrm{C}} 167.8\left(\mathrm{C}-7^{\prime \prime \prime}\right)$. Based on the above results, the structure of cucurbitoside A (1) was established as 2-(4hydroxyphenyl)ethanol 4- $O$-(5- $O$-benzoyl)- $\beta$-D-apiofurano$\operatorname{syl}(1 \rightarrow 2)-\beta$-D-glucopyranoside.

Cucurbitoside B (2) was isolated as an amorphous powder. The molecular formula was established as $\mathrm{C}_{26} \mathrm{H}_{32} \mathrm{O}_{13}$ by HRFAB-MS. On acid hydrolysis, 2 afforded D-glucose and Dapiose as component sugars. The ${ }^{1} \mathrm{H}$ - and ${ }^{13} \mathrm{C}$-NMR spectra of 2 showed signals due to a 2-(4-hydroxyphenyl)ethanol group, a $\beta$-D-glucopyranose group and a $\beta$-D-apiofuranonose group. Besides the similar signals as those of $\mathbf{1}$, the proton signals assignable to an $\mathrm{A}_{2} \mathrm{X}_{2}$ type aromatic ring at $\delta 7.79$ $(2 \mathrm{H}, \mathrm{d}, J=8.9 \mathrm{~Hz})$ and $6.75(2 \mathrm{H}, \mathrm{d}, J=8.9 \mathrm{~Hz})$, coupled with information from the ${ }^{13} \mathrm{C}-\mathrm{NMR}$ ( $\delta$ 167.8, 163.6, 116.2, $133.0,122.0)$, suggested the presence of a 4-hydroxybenzoyl moiety. The placement of the 4-hydroxybenzoyl moiety at $5^{\prime \prime}$ $\mathrm{OH}$ of $\beta$-D-apiofuranose was confirmed by the correlations between $\delta_{\mathrm{H}} 4.29,4.22\left(\right.$ Api-H"-5) and $\delta_{\mathrm{C}} 167.8\left(\mathrm{C}-7^{\prime \prime \prime}\right)$ in the HMBC spectrum (Fig. 1). Thus, the structure of cucurbitoside B (2) was established as 2-(4-hydroxyphenyl)ethanol 4$O$-[5- $O$-(4-hydroxy)benzoyl]- $\beta$-D-apiofuranosyl $(1 \rightarrow 2)-\beta$-Dglucopyranoside.
Table 2. ${ }^{13} \mathrm{C}-\mathrm{NMR}$ Data of $\mathbf{1}-\mathbf{5}$ in $\mathrm{CD}_{3} \mathrm{OD}$

\begin{tabular}{lrrrrr}
\hline \hline Position & \multicolumn{1}{c}{$\mathbf{1}$} & $\mathbf{2}$ & $\mathbf{3}$ & $\mathbf{4}$ & $\mathbf{5}$ \\
\hline 1 & 134.1 & 134.1 & 136.5 & 136.5 & 152.2 \\
2 and 6 & 130.9 & 130.9 & 129.4 & 129.5 & 118.8 \\
3 and 5 & 117.4 & 117.4 & 117.2 & 117.2 & 116.7 \\
4 & 157.3 & 157.4 & 158.1 & 158.2 & 153.7 \\
7 & 39.4 & 39.4 & 64.8 & 64.9 & \\
8 & 64.3 & 64.4 & & & \\
Glc-1' & 100.9 & 100.9 & 100.7 & 100.8 & 101.9 \\
$2^{\prime}$ & 78.4 & 78.3 & 78.4 & 78.4 & 78.5 \\
$3^{\prime}$ & 78.9 & 78.9 & 78.8 & 78.9 & 78.9 \\
$4^{\prime}$ & 71.7 & 71.6 & 71.6 & 71.6 & 71.7 \\
$5^{\prime}$ & 78.1 & 78.1 & 78.1 & 78.1 & 78.0 \\
$6^{\prime}$ & 62.6 & 62.6 & 62.6 & 62.6 & 62.6 \\
Api-1" & 110.5 & 110.5 & 110.5 & 110.5 & 110.5 \\
$2^{\prime \prime}$ & 78.7 & 78.8 & 78.7 & 78.8 & 78.7 \\
$3^{\prime \prime}$ & 79.2 & 79.3 & 79.2 & 79.3 & 79.3 \\
$4^{\prime \prime}$ & 75.5 & 75.5 & 75.5 & 75.4 & 75.5 \\
$5^{\prime \prime}$ & 68.5 & 68.0 & 68.5 & 67.9 & 68.4 \\
$1^{\prime \prime \prime}$ & 131.2 & 122.0 & 131.1 & 122.0 & 131.2 \\
$2^{\prime \prime \prime}$ & 130.7 & 133.0 & 130.7 & 133.0 & 130.7 \\
$3^{\prime \prime \prime}$ and 6"' and 5"' & 129.6 & 116.2 & 129.6 & 116.2 & 129.6 \\
$4^{\prime \prime \prime}$ & 134.3 & 163.6 & 134.3 & 163.6 & 134.4 \\
$7^{\prime \prime \prime}$ & 167.8 & 167.8 & 167.7 & 167.8 & 167.8 \\
& & & & & \\
\hline & & & & &
\end{tabular}


Cucurbitoside $\mathrm{C}(\mathbf{3})$ was isolated as an amorphous powder. The molecular formula was established as $\mathrm{C}_{25} \mathrm{H}_{30} \mathrm{O}_{12}$ by HRFAB-MS. On acid hydrolysis, 3 afforded D-glucose and Dapiose as component sugars. In comparison of the ${ }^{1} \mathrm{H}$ - and ${ }^{13} \mathrm{C}-\mathrm{NMR}$ spectra of $\mathbf{3}$ with those of $\mathbf{1}$, the signals due to sugars and the benzoyl group were superimposable, while some differences were observed for the signals due to the aglycon. The absence of a methylene signal in 3, suggested the aglycon to be 4-hydroxybenzyl alcohol. The placement of the hydroxymethyl and the sugar unit at C-1 and C-4 was further confirmed by the HMBC data (Fig. 1), which showed important correlations between $\delta_{\mathrm{H}} 4.41\left(\mathrm{H}_{2}-7\right) / \delta_{\mathrm{C}} 129.4(\mathrm{C}-2,6)$, and $\delta_{\mathrm{H}} 4.95\left(\mathrm{Glc}-\mathrm{H}-1^{\prime}\right) / \delta_{\mathrm{C}} 158.1$ (C-4). Thus, the structure of cucurbitoside $\mathrm{C}$ (3) was determined as 4-hydroxybenzyl alcohol $\quad 4-O$-(5-O-benzoyl)- $\beta$-D-apiofuranosyl $(1 \rightarrow 2)-\beta$-Dglucopyranoside.

Cucurbitoside D (4) was isolated as an amorphous powder. The molecular formula was established as $\mathrm{C}_{25} \mathrm{H}_{30} \mathrm{O}_{13}$ by HRFAB-MS. The superimposable signals due to the aglycon and component sugars in the ${ }^{1} \mathrm{H}$ - and ${ }^{13} \mathrm{C}$-NMR spectra between 4 and 3, together with the result of acid hydrolysis, suggested 4 is only different by one aromatic ring from 3 . In the ${ }^{1} \mathrm{H}$ NMR spectrum, comparing with that of $\mathbf{3}$, the proton signals due to the aromatic ring of the benzoyl group were changed from monosubstitution to 1,4-disubstitution at $\delta 7.79(2 \mathrm{H}, \mathrm{d}$, $J=9.0 \mathrm{~Hz})$ and $6.75(2 \mathrm{H}, \mathrm{d}, J=9.0 \mathrm{~Hz})$. Further comparison of the NMR data of $\mathbf{4}$ and $\mathbf{2}$, suggested $\mathbf{4}$ had the same 4-hydroxybenzoyl group as $\mathbf{2}$. Analysis of the HMBC correlations also supported the result (Fig. 1). Thus, the structure of cucurbitoside D (4) was established as 4-hydroxybenzyl alcohol 4- $O$-[5- $O$-(4-hydroxy)benzoyl]- $\beta$-D-apiofuranosyl $(1 \rightarrow 2)-\beta$ D-glucopyranoside.

Cucurbitoside E (5) was isolated as an amorphous powder. The molecular formula was established as $\mathrm{C}_{24} \mathrm{H}_{28} \mathrm{O}_{12}$ by HRFAB-MS. Its ${ }^{1} \mathrm{H}$ - and ${ }^{13} \mathrm{C}-\mathrm{NMR}$ spectra, together with the result of acid hydrolysis, suggested the presence of a $\beta$-D-glucopyranose, a $\beta$-D-apiofuranonose and a benzoyl group in $\mathbf{5}$, the same as in $\mathbf{1}$ and $\mathbf{3}$. Further analysis of the NMR data of $\mathbf{5}$ suggested the aglycon to be 4-hydroxyphenol. Thus, the structure of cucurbitoside E (5) was established as 4hydroxyphenyl $\quad 5$ - $O$-benzoyl- $\beta$-D-apiofuranosyl $(1 \rightarrow 2)-\beta$-Dglucopyranoside.

In conclusion, from the seeds of $C$. moschata, we have isolated a novel type of phenolic glycosides, including cucurbitosides $\mathrm{A}-\mathrm{E}(\mathbf{1}-\mathbf{5})$, which bear $\beta$-D-apiofuranosyl $(1 \rightarrow 2)$ $\beta$-D-glucopyranose as a sugar chain, and an ester linkage of the benzoyl or 4-hydroxybenzoyl moiety at C-6 of apiofuranose. We are now engaged in the chemical investigation to determine if these similar components are characteristic of the genus Cucurbita.

\section{Experimental}

General Experimental Procedures The UV spectra were obtained with a Shimadzu UV-160 spectrophotometer, whereas the IR spectra were measured with a JASCO FT/IR-300E (by a KBr disk method) spectrometer. Optical rotations were measured with a JASCO DIP-370 digital polarimeter in a $0.5-\mathrm{dm}$ cell. The FAB-MS and HR-FAB-MS were taken on a JEOL JMS700 Mstation spectrometer. The ${ }^{1} \mathrm{H}-$ and ${ }^{13} \mathrm{C}-\mathrm{NMR}$ spectra were measured with a JEOL ECP-500 spectrometer with TMS as the internal reference, and chemical shifts are expressed in $\delta$ (ppm). For HPLC, a JASCO PU-1580 HPLC system, equipped with a Shodex RI-71 Differential Refractometer detector, was used. Reversed-phase CC was accomplished with RP-C18 silica gel (Chromatotex DM1020T ODS, Fuji Silysia Chemical Ltd.). TLC was conducted in Kieselgel $60 \mathrm{~F}_{254}$ plates (E. Merck). GLC was carried out on a PerkinElmer Clarus 500 GC-MS instrument.

Extraction and Isolation The seeds of C. moschata were purchased from The Seeds Company of Heilongjiang Province, China. The seeds $(2.0 \mathrm{~kg})$ were extracted with $\mathrm{MeOH}$ with ultrasonic treatment three times for $1 \mathrm{~h}$ each at room temperature. The methanolic extract was concentrated (64 g), suspended in $\mathrm{H}_{2} \mathrm{O}$ and then partitioned successively with EtOAc. The $\mathrm{H}_{2} \mathrm{O}$ layer was passed through a Diaion HP-20 column, and washed with $\mathrm{H}_{2} \mathrm{O}$ and $\mathrm{MeOH}$. The $\mathrm{MeOH}$ fraction $(2.4 \mathrm{~g})$ was chromatographed over ODS CC eluted with $40 \%$ and $80 \% \mathrm{MeOH}$ to give two fractions A (1.2 g) and $\mathrm{B}(0.8 \mathrm{~g})$. Further purification of fraction $\mathrm{A}$ by repeated preparative HPLC with $40 \% \mathrm{MeOH}$ and $20 \% \mathrm{CH}_{3} \mathrm{CN}$ afforded five compounds, 1 (21 mg), 2 (14 mg), 3 (22 mg), 4 (11 mg), and 5 (2 mg).

Cucurbitoside A (1): Amorphous powder, $[\alpha]_{\mathrm{D}}^{25}-76.1^{\circ}(c=1.1, \mathrm{MeOH})$; $\mathrm{UV}(\mathrm{MeOH}) \lambda_{\max } \mathrm{nm}(\log \varepsilon): 366$ (2.03), 273 (3.20), 224 (4.15). IR (KBr) $v_{\max }: 3412,1711,1600,1517,1468,1277 \mathrm{~cm}^{-1}$. ${ }^{1} \mathrm{H}-\mathrm{NMR}(500 \mathrm{MHz}$, $\left.\mathrm{CD}_{3} \mathrm{OD}\right)$ and ${ }^{13} \mathrm{C}-\mathrm{NMR}\left(125 \mathrm{MHz}, \mathrm{CD}_{3} \mathrm{OD}\right)$ : See Tables 1 and 2. FAB-MS (positive) $\mathrm{m} / \mathrm{z} 559 \quad[\mathrm{M}+\mathrm{Na}]^{+}$. HR-FAB-MS (positive) $\mathrm{m} / \mathrm{z} 559.1772$ $[\mathrm{M}+\mathrm{Na}]^{+}$(Calcd for $\mathrm{C}_{26} \mathrm{H}_{32} \mathrm{O}_{12} \mathrm{Na}, 559.1791$ ).

Cucurbitoside B (2): Amorphous powder, $[\alpha]_{\mathrm{D}}^{25}-65.9^{\circ}(c=0.4, \mathrm{MeOH})$; $\mathrm{UV}(\mathrm{MeOH}) \lambda_{\max } \mathrm{nm}(\log \varepsilon): 259$ (4.08). IR (KBr) $v_{\mathrm{max}}: 3413,1696,1607$, $1518,1449,1276 \mathrm{~cm}^{-1}$. ${ }^{1} \mathrm{H}-\mathrm{NMR}\left(500 \mathrm{MHz}, \mathrm{CD}_{3} \mathrm{OD}\right)$ and ${ }^{13} \mathrm{C}-\mathrm{NMR}$ $\left(125 \mathrm{MHz}, \mathrm{CD}_{3} \mathrm{OD}\right.$ ): See Tables 1 and 2. FAB-MS (positive) $\mathrm{m} / \mathrm{z} 575$ $[\mathrm{M}+\mathrm{Na}]^{+}$. HR-FAB-MS (positive) $\mathrm{m} / z 575.1749$ [M+Na $^{+}$(Calcd for $\mathrm{C}_{26} \mathrm{H}_{32} \mathrm{O}_{13} \mathrm{Na}, 575.1740$ ).

Cucurbitoside C (3): Amorphous powder, $[\alpha]_{\mathrm{D}}^{25}-81.5^{\circ}(c=1.1, \mathrm{MeOH})$; $\mathrm{UV}(\mathrm{MeOH}) \lambda_{\max } \mathrm{nm}(\log \varepsilon): 366$ (2.04), 273 (3.18), 225 (4.21). IR (KBr) $v_{\max }: 3403,1710,1647,1517,1468,1278 \mathrm{~cm}^{-1}$. ${ }^{1} \mathrm{H}-\mathrm{NMR}(500 \mathrm{MHz}$, $\left.\mathrm{CD}_{3} \mathrm{OD}\right)$ and ${ }^{13} \mathrm{C}$-NMR $\left(125 \mathrm{MHz}, \mathrm{CD}_{3} \mathrm{OD}\right)$ : See Tables 1 and 2. FAB-MS (positive) $\mathrm{m} / \mathrm{z} \quad 545 \quad[\mathrm{M}+\mathrm{Na}]^{+}$. HR-FAB-MS (positive) $\mathrm{m} / \mathrm{z} \quad 545.1629$ $[\mathrm{M}+\mathrm{Na}]^{+}$(Calcd for $\mathrm{C}_{25} \mathrm{H}_{30} \mathrm{O}_{12} \mathrm{Na}, 545.1635$ ).

Cucurbitoside D (4): Amorphous powder, $[\alpha]_{\mathrm{D}}^{25}-76.9^{\circ}(c=0.9, \mathrm{MeOH})$; $\mathrm{UV}(\mathrm{MeOH}) \lambda_{\max } \mathrm{nm}(\log \varepsilon): 259$ (4.10). IR (KBr) $v_{\max }: 3430,1698,1629$, $1517,1468,1273 \mathrm{~cm}^{-1}$. ${ }^{1} \mathrm{H}-\mathrm{NMR}\left(500 \mathrm{MHz}, \mathrm{CD}_{3} \mathrm{OD}\right)$ and ${ }^{13} \mathrm{C}-\mathrm{NMR}$ $\left(125 \mathrm{MHz}, \mathrm{CD}_{3} \mathrm{OD}\right.$ ): See Tables 1 and 2. FAB-MS (positive) $\mathrm{m} / \mathrm{z} 561$ $[\mathrm{M}+\mathrm{Na}]^{+}$. HR-FAB-MS (positive) $\mathrm{m} / z$ $561.1568[\mathrm{M}+\mathrm{Na}]^{+}$(Calcd for $\left.\mathrm{C}_{25} \mathrm{H}_{30} \mathrm{O}_{13} \mathrm{Na}, 561.1584\right)$.

Cucurbitoside E (5): Amorphous powder, $[\alpha]_{\mathrm{D}}^{25}-77.0^{\circ}(c=0.3, \mathrm{MeOH})$; $\mathrm{UV}(\mathrm{MeOH}) \lambda_{\max } \mathrm{nm}(\log \varepsilon): 284$ (3.40), 225 (4.11). IR (KBr) $v_{\max }: 3414$, $1709,1629,1518,1468 \mathrm{~cm}^{-1} .{ }^{1} \mathrm{H}-\mathrm{NMR}\left(500 \mathrm{MHz}, \mathrm{CD}_{3} \mathrm{OD}\right)$ and ${ }^{13} \mathrm{C}-\mathrm{NMR}$ $\left(125 \mathrm{MHz}, \mathrm{CD}_{3} \mathrm{OD}\right.$ ): See Tables 1 and 2. FAB-MS (positive) $\mathrm{m} / \mathrm{z} 531$ $[\mathrm{M}+\mathrm{Na}]^{+}$. HR-FAB-MS (positive) $\left.\mathrm{m} / z 531.1478{ }^{\mathrm{M}+\mathrm{Na}}\right]^{+}$(Calcd for $\mathrm{C}_{24} \mathrm{H}_{28} \mathrm{O}_{12} \mathrm{Na}, 531.1478$ ).

Acid Hydrolysis and Determination of the Absolute Configuration of Sugars in $\mathbf{1}-\mathbf{5}$ Each solution of $\mathbf{1}-\mathbf{5}$ (each $0.5 \mathrm{mg}$ ), in $1 \mathrm{M} \mathrm{HCl}$ (dioxane $-\mathrm{H}_{2} \mathrm{O}, 1: 1,200 \mu \mathrm{l}$ ) was heated at $100^{\circ} \mathrm{C}$ for $1 \mathrm{~h}$ under an $\mathrm{Ar}$ atmosphere. After dioxane was removed, the solution was extracted with EtOAc $(1 \mathrm{ml} \times 3)$ to remove the aglycon. The aqueous layer was neutralized by passing through an ion-exchange resin (Amberlite MB-3, Organo, Tokyo, Japan) column, concentrated under reduced pressure to dryness, to give a residue of the sugar fraction. The residue was dissolved in pyridine $(0.1 \mathrm{ml})$, to which $0.08 \mathrm{M} \mathrm{L}$-cysteine methyl ester hydrochloride in pyridine $(0.15 \mathrm{ml})$ was added. The mixture was kept at $60^{\circ} \mathrm{C}$ for $1.5 \mathrm{~h}$. After the reaction mixture was dried in vacuo, the residue was trimethylsilylated with 1-trimethylsilylimidazole $(0.1 \mathrm{ml})$ for $2 \mathrm{~h}$. The mixture was partitioned between hexane and $\mathrm{H}_{2} \mathrm{O}(0.3 \mathrm{ml}$ each) and the hexane extract was analyzed by GC-MS under the following conditions: capillary column, EQUITYTM-1 $\left(30 \mathrm{~m} \times 0.25 \mathrm{~mm} \times 0.25 \mu \mathrm{m}\right.$, Supelco), column temperature, $230^{\circ} \mathrm{C}$; injection temperature, $250^{\circ} \mathrm{C}$; carrier $\mathrm{N}_{2}$ gas. In the acid hydrolysate of $\mathbf{1}-\mathbf{5}$, D-glucose and D-apiose were confirmed by comparison of the retention times of their derivatives with those of D-glucose, L-glucose and D-apiose derivatives prepared in a similar way, which showed retention times of 11.02, 11.43 and $6.11 \mathrm{~min}$, respectively.

\section{References}

1) Shanghai Scientific Technological Publisher (eds.) "Zhong hua ben cao," Vol. 5, Shanghai, 1985, pp. 528-529.

2) Hase K., Kadota S., Basnet P., Namba T., Takahashi T., Phytother. Res., 10, 387-392 (1996).

3) Xia H. C., Li F., Li Z., Zhang Z. C., Cell Res., 13, 369-374 (2003).

4) Murkovic M., Hillebrand A., Winkler J., Leitner E., Pfannhauser W., $Z$. Lebensm. Unters. For., 203, 216-219 (1996).

5) EI-Adawy T. A., Taha K. M., J. Agric. Food Chem., 49, 1253-1259 (2001). 
6) Yoshida H., Shougaki Y., Hirakawa Y., Tomiyama Y., Mizushina Y., $J$. Sci. Food Agric., 84, 158-163 (2004).

7) Hara S., Okabe H., Mihashi K., Chem. Pharm. Bull., 35, 501-506 (1987).
8) Kitagawa I., Hori K., Sakagami M., Hashiuchi F., Yoshikawa M., Ren J., Chem. Pharm. Bull., 41, 1350-1357 (1993). 